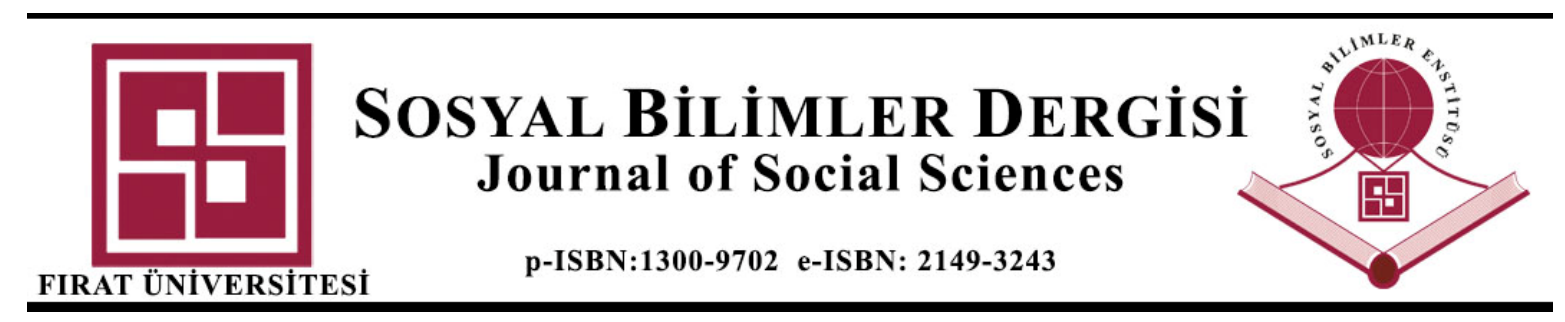

\title{
MURAT HÖYÜK ERKEN TUNÇ ÇAĞI HAYVAN FIGÜRINLERİ
}

\section{Early Bronze Age Animal Figurines from Murat Höyük}

\begin{abstract}
Abdulkadir ÖZDEMIR ${ }^{1}$
${ }^{l}$ Dr. Öğr. Üyesi, Fırat Üniversitesi, Insani ve Sosyal Bilimler Fakültesi, Arkeoloji Bölümü, Elazı̆̆, aozdemir@firat.edu.tr, orcid.org/0000-0003-3333-9118
\end{abstract}

Makale Bilgisi
Geliş/Received:
20.01 .2021
Kabul/Accepted:
26.03 .2021
DOI:
10.18069/firatsbed. 865423

Anahtar Kelimeler
Erken Tunç Çağl,
Figürinler, Hayvan
Figürinleri, Murat Höyük,
Bingöl, Doğu Anadolu

Araştırma Makalesi/Research Article

ÖZ

Bu çalışma, Bingöl İli Solhan İlçesi, Murat Nehri kenarında yer alan Murat Höyük’te 2019 yılında yapılan kurtarma kazısı sonucunda ele geçen pişmiş toprak (kil) hayvan figürinlerini tanıtmaktadır. İsmini içerisinde yer aldığı Murat Köyü’nden alan höyük, Bingöl'ün ilk sistemli arkeolojik kazısıdır. Höyük, Aşağı Kaleköy Barajı su tutma havzası içerisindedir ve bu nedenle Elazığ Müzesi Müdürlüğü tarafından 2018 yılında tescillenmiştir. Elazı ̆̆ Müzesi Müdürlüğü kazı başkanlığında ve bilimsel bir heyet tarafından 2019 yılında kurtarma kazısı çalışmaları yapılarak tamamlanmıştır. 2019 yılında tamamlanan arkeolojik kazılar sonucunda höyükte 4 kültür tabakası tespit edilmiştir. Murat Höyük’ten ele geçen ve çalışmaya konu olan hayvan figürinleri Erken Tunç Çağı III'e tarihlendirilmektedir. Anadolu arkeolojik materyal kültüründe ele geçen hayvan figürinleri pişmiş toprak (kil), metal ve taş olarak karşımıza çıkmaktadır. Bu gruplar içerisinde Murat Höyük figürinleri pişmiş toprağa dâhildir. Çalışmalarda 9 adet hayvan figürini ortaya çıkarılmıştır. Tamamı el yapımı olan bu figürinlerin 7 tanesi boğa, 2 tanesi koç/koyun betimlemelidir. Figürinlerin tamamı kısmi kırıklara sahiptir. Yüz detayları oldukça deforme olmuştur. Ayakları kırık olsa da ayakta durur pozisyonda işlenmişlerdir. Boynuz ve kuyruk detayları görülmektedir. Anatomik yapısı ile güçlü vücut yapılarına sahiptirler. Murat Höyük’te pişmiş toprak (kil) tekerlekler de ele geçmiştir. Bazı hayvan figürinlerinin avluda tekerlekler ile birlikte ele geçmesi, bunların boğa/öküzler tarafından çekilen kağnı türü veya dört tekerlekli vagon şeklindeki oyuncak olarak kullanılan minyatür arabaların parçası olabileceğini düşündürmektedir. Murat Höyük'te ele geçen hayvan figürinlerinin, Doğu Anadolu Erken Tunç Çağı toplumlarının sanat, ritüel ve inanç sistemlerinin anlaşılmasına katkı sağlayacağı düşünülmektedir.

Keywords Early Bronze Age, Figürines, Zoomorphic Figürines, Murat Höyük, Bingöl, Eastern Anatolia

\begin{abstract}
This study presents a group of terracotta animal figurines found in 2019 at Murat Höyük excavations. Murat Höyük lies on the bank of the Murat River in Solhan district of Bingöl province, nearby Murat village (its namesake), and it is the first systematically excavated archaeological site in Bingöl. The mound is located in the reservoir of the Aşağ 1 Kaleköy Dam, so it was registered as a threatened archaeological site in 2018 and salvage excavations were initiated and completed in 2019 by a team of specialists under the directorship of Elazı $\breve{g}$ Museum, prior to its inundation. Excavations documented four main settlement phases. Zoomorphic figurines presented in this study come from the EBA III level. In Anatolia, the known repertoire of zoomorphic figurines includes examples made of baked clay (terracotta), metal and stone. Murat Höyük animal figurines are all made of clay and formed by hand. Nine animal figurines were found at the site, seven of which depict bulls and two depict ram/sheep. All figurines are partially broken, and facial details are abraded. Although legs are also broken, preserved stumps show that they were depicted in standing position. Horns and tails are easily distinguishable. The animals have a robust body form. Terracotta wheels were also discovered at Murat Höyük. Some of the animal figurines were found in the same courtyard as the wheels, suggesting that they may have belonged to terracotta models of two-wheeled tumbler carts or four-wheeled wagons drawn by bulls/oxen. Animal figurines found in Murat Höyük provide new datasets for our understanding of art, rituals and belief systems of the Early Bronze Age communities in Eastern Anatolia.
\end{abstract}

Atıf/Citation: ÖZDEMIR, A., (2021). Murat Höyük Erken Tunç Çağı Hayvan Figürinleri, Fırat Üniversitesi Sosyal Bilimler Dergisi, 31, 2(567-582).

Sorumlu yazar/Corresponding autohor: Abdulkadir ÖZDEMİ, aozdemir@firat.edu.tr 


\section{Giriș}

Toplulukları oluşturan insan var olduğu günden beri doğaya uyum sağlamaya çalışmıştır. Yaşamak için temel ihtiyaçlarını karşılamayı öğrenmiştir. Doğayla iç içe yaşamayı öğrenmeleri ve temel yaşam şartlarının önemli kısmını tamamlamaları Paleolitik Dönem ile birlikte oluşmuştur (Özdoğan, 2002a: 55-57). Yaşamın her anında olduğu gibi bu dönemde de hayvanlarla birlikte yaşamayı öğrenmiş ve onlarla dünyayı paylaşmıştır. Besin, giyinme gibi temel ihtiyaçları dahilinde hayvanları av olarak gören insan zaman ilerledikçe onlarla sanatsal ve inançsal bağlar kurmaya başlamıştır. Bu bağlamda Üst Paleolitik Dönem ile birlikte çevresinde gördüklerini mağara ve kaya sığınaklarının duvarlarına resmetmeye başlamış, yontma tekniği ile idoller ve figürinler elde etmişlerdir. Böylece dönem içerisinde belli bir sanat anlayışı ortaya çıkmıştır (Aydıngün, 2006: 12).

Zamanla avcı toplayıcılığa dayalı göçebe hayatın yerini, yerleşik ve tarıma dayalı bir toplum yapısı almaya başlamıştır (Özdoğan, 2002b: 66). Neolitik ile birlikte gelen yerleşik yaşam tarzı, tek bir beslenme modelinin olmadığı göstermekle birlikte, tarım ve hayvanların evcilleştirilmesi toplumların yaşam tarzlarının yeniden şekillenmesine neden olmuştur. Böylelikle topluluklar, çevre koşullarına göre kendi ekinlerini üretmeye ve hayvanlarını beslemeye başlamıştır (Özdoğan, 2007: 455). Tarımsal faaliyetlerin artması ile belli depolama alanlarına, kamusal alanlara ve dini alanlara ihtiyaç duymaya başlanmıştır. Neolitik Dönem ile yeni teknolojiler, uzman ustalar ve yeni alet türleri ortaya çıkmıştır (Özdoğan, 2007: 452). Dönemin en büyük yeniliklerinden biri de kilin çanak çömlek yapımında kullanılmaya başlamasıdır. Bu da teknolojik anlamda ilerlemeleri göstermektedir. Anadolu'da Neolitik Dönem'de gerçeğe yakın, doğal işlenen kadın figürinleri Kalkolitik Dönem ile birlikte kısmen stilize işlenmeye başlanmıştır. Geç Kalkolitik Dönem ile stilize tasvirler artmış ve Erken Tunç Çağı ile birlikte de soyut figürler karşımıza çıkmaktadır (Bilge, 2009: 46).

Anadolu'da, Erken Tunç Çağı kendinden önceki dönemlere kıyasla daha yoğun bir şekilde iskan faaliyetlerinin görüldüğü ve önemli değişimlerin yaşandığı bir dönemdir. Anadolu coğrafyası için Erken Tunç Çağı'nda toplumsal sınıflanmanın oluşumunu tamamladığı, sosyo-politik bir otoritenin yani merkezileşmenin ortaya çıktığı, bakır/kalay alaşımı olan tunç kullanımı ile metalin önem kazandığı, uzun mesafeli ticaretin geliştiği ve bunlara bağlı olarak sosyal karmaşıklığa neden olan ekonomik ve sosyal gelişmelerin yaşandığı, yerleşim sayısında artış görüldüğü bir dönemdir (Çevik, 2007: 131-138).

Anadolu'da Neolitik Dönem itibariyle Erken Tunç Çağı sonuna kadar önemli bir tematik değişim olmadan benzer üsluba sahip figürinler üretilmeye devam etmiştir (Ayten, 2019: 15). Erken Tunç Çağı kullanılan materyal olarak da farklılık yaratmıştır. Erken Tunç Çağı yerleşimlerinde taş, kil ve metal olmak üzere üç hammaddenin kullanıldığı görülmektedir. Yerleşimlerde hammadde olarak en yaygın kil kullanılmıştır. Kil hem işlevsel hem de ekonomik açıdan daha elverişlidir. Dönem içerisinde metal işçiliğinin gelişmesi ile metal hayvan figürinleri de görülmektedir. Özellikle mezarlardan ele geçen örneklerde fiziksel özellikler detaylı olarak işlenmiştir. Metal hayvan figürinlerinde de boynuzlu hayvanlar (sığır, geyik gibi) betimlenmiştir (Özgüç ve Akok, 1958).

Bu çalışmada, Murat Höyük’ten ele geçmiş dokuz adet pişmiş toprak hayvan figürininin değerlendirilmesi amaçlanmaktadır. Öncelikle Murat Höyük'ün Erken Tunç III'e tarihlenen tabakası arkeolojik veriler ile açıklanarak, hayvan figürinlerinin Anadolu'da az sayıdaki örnekleri 1şı̆̆ında tipolojik değerlendirmeleri, kullanım amacı ve yayılım alanı hakkında ne tür bilgiler sunduğu açıklanmaya çalışılacaktır. Ayrıca mevcut veriler 1şığında, Erken Tunç Çağı'ndaki pişmiş toprak hayvan figürinlerin Anadolu'da görülen benzerlerine değinilecektir. Bunlara ek olarak, yerleşimin IV. katından ele geçen tekerlekler ile avluda birlikte bulunan hayvan figürinlerinin, boğa/öküzler tarafından çekilen iki tekerlekli kağnı türü veya dört tekerlekli vagon şeklindeki oyuncak olarak kullanılan minyatür bir araba modeline ait olabileceği önerileri, değerlendirme ve sonuç kısmında açıklanmaya çalışılacaktır.

\section{Erken Tunç Çağı'nda Murat Höyük}

Murat Höyük, ${ }^{1}$ Bingöl İli’nin 40 km doğusunda, Solhan İlçesi’nin 12 km güneybatısında, Murat Köyü’nün 230 m güneyindedir (Şekil 1). Höyük, denizden +1088 m yükseklikte, 140x120 m boyutlarındadır. Dikdörtgen

\footnotetext{
${ }^{1}$ Murat Höyük hakkında detaylı bilgi için bkz. Özdemir, 2020: 272-287.
} 


\section{F.Ü. Sosyal Bilimler Dergisi 2021-31/2}

formlu olan höyük doğal bir tepe üzerinde yer almaktadır (Şekil 2). Murat Nehri kenarında konumlanan höyük, Kalehan Genç Enerji A.Ş. tarafından yapılan Aşağı Kaleköy Barajı ve HES kapasite artırımı projesi kapsamında su tutma havzası içerisinde yer almaktadır. Aynı havza içinde yer alan 2018 yılı Murat Tepe ${ }^{2}$ kurtarma kazıları sırasında bu çalışmanın yazarı tarafından keşfedilen höyük, 2018 yılında Elazığ Müze Müdürlüğü tarafından tescile önerilmiş ve aynı yıl höyükte sondaj kazıları yapılarak Erzurum Kültür Varlıklarını Koruma Bölge Kurulu tarafından tescillenmiştir. Höyükte kurtarma kazı çalışmalarına 2019 yılında başlanmış ve aynı yıl çalışmalar tamamlanmıştır. 2018 yılı Murat Tepe ve 2019 yılı Murat Höyük’te yapılan kurtarma kazı çalışmaları, Bingöl bölgesinin ilk sistemli arkeolojik kazılarıdır.

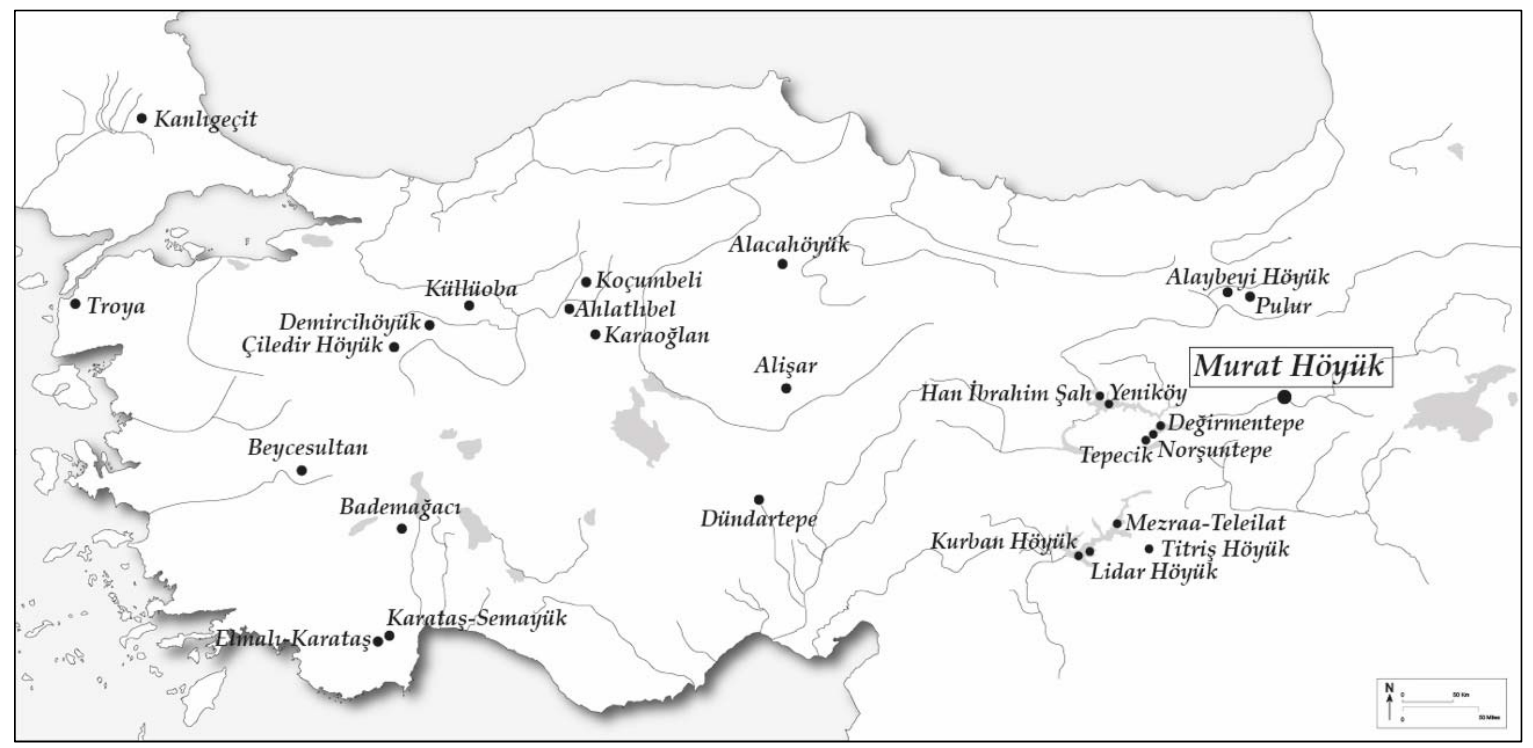

Şekil 1. Erken Tunç Çağı'nda Murat Höyük konumu ve metinde adı geçen pişmiş toprak hayvan figürini ele geçen yerleşimler (Çizim: Abdulkadir Özdemir).

Murat Höyük’te tamamlanan arkeolojik çalışmalar sonucunda dört kültür tabakası tespit edilmiştir. İlk defa Erken Tunç Çağı'nda iskan edilen höyükte Erken Demir Çağı, Orta Demir Çağı ve son olarak Orta Çağ karşımıza çıkmaktadır (Tablo 1).

Tablo 1. Murat Höyük ana kültür evrelerini gösteren tablo.

\begin{tabular}{lll}
\hline Kültür Katı & Yaklaşık Kalibre Tarihleri & Görece Kronoloji \\
\hline Murat Höyük I & MS 9-10 yy & Orta Çă̆ \\
Murat Höyük II & MÖ 9-6 yy & Orta Demir-Urartu \\
\hline Murat Höyük III & MÖ 12-10 yy & Erken Demir \\
\hline Murat Höyük IV & MÖ 2500-2200 & Erken Tunç III \\
\hline
\end{tabular}

Murat Höyük'ün IV. tabakası Erken Tunç Çağı III'e tarihlenmektedir. Höyükte mimari yapı içerisinden alınan numunelerden TUBİTAK MAM laboratuvarlarında yapılan Karbon 14 testleri sonucunda Erken Tunç Çağı tabakası MÖ 2500-2200 arasına tarihlendirilmektedir (Özdemir, 2020: 274-275). Erken Tunç Çağı tabakasına ait taş temel üzerine kerpiç duvarlardan inşa edilmiş dikdörtgen planlı ve tek odalı yapılar bulunmaktadır.

${ }^{2}$ Murat Tepe hakkında detaylı bilgi için bkz. Özdemir ve diğerleri, 2020: 1-14. 
Yapıların tabanları sıkıştırılmış sert toprak ile taban oluşturulmuştur. Yerleşimde dikdörtgen planlı mekânların yanı sıra, mimari yapılar arasında yer alan ve avlu olarak adlandırılan alanda ise günlük yaşam faaliyetlerine tanıklık eden besin üretiminin gerçekleştirildiği taş döşemeli seki ve bu seki etrafında öğütme taşları bulunmuştur. Ayrıca avluda çamur sıvalı dairesel formda yemek pişirme eylemini kanıtlayan ocak kalıntısı bulunması, insanların avlularda toplu halde bir araya geldikleri ve daha çok besin hazırlama ve tüketme aşamalarına yönelik gündelik aktivitelerini gerçekleştirdikleri mekânların kolektif hareket edilen bir topluluğun olduğuna işaret etmektedir.

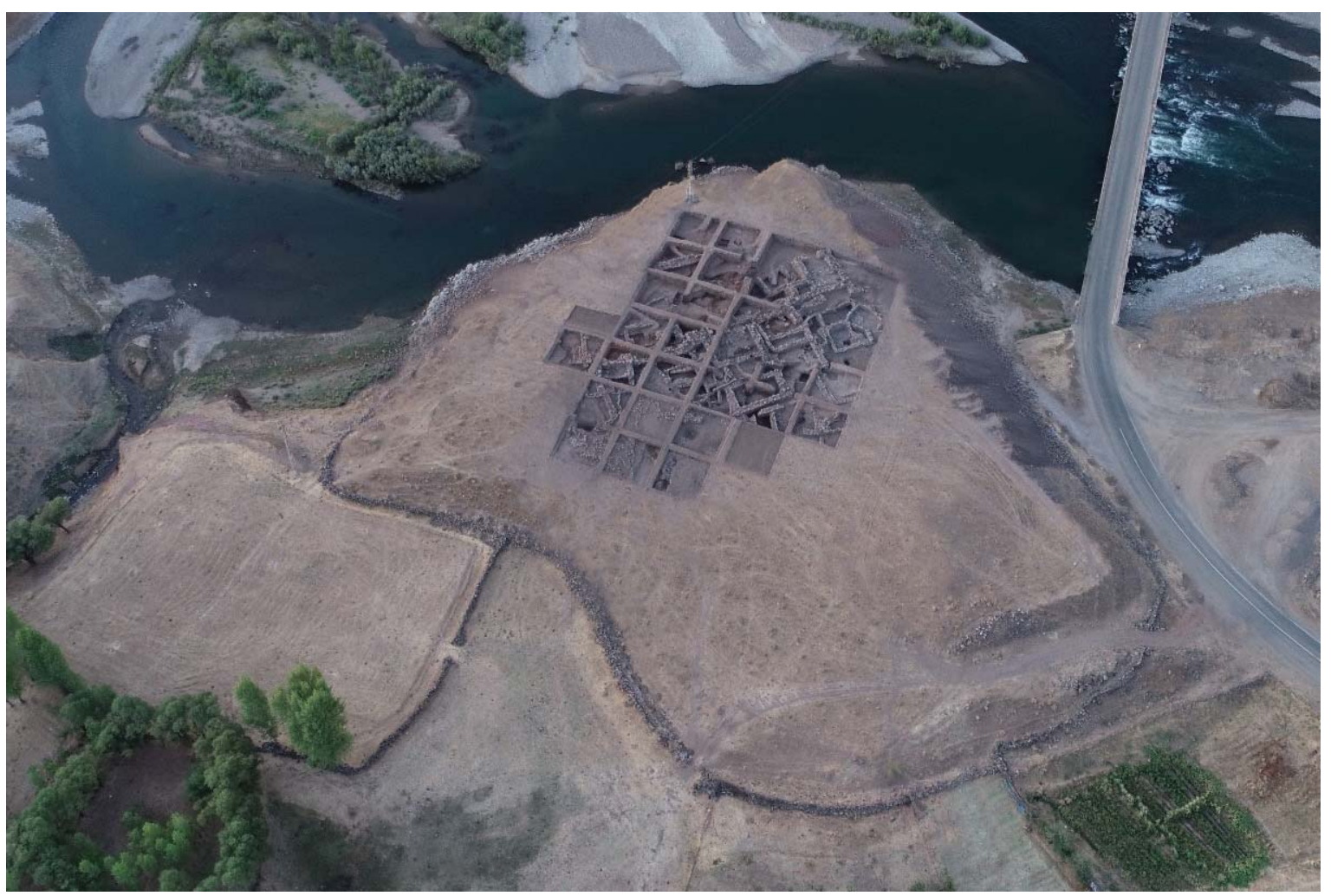

Şekil 2. Murat Nehri kenarındaki Murat Höyük havadan genel görünümü (Murat Höyük Kazı Arşivi).

Murat Höyük’te, Erken Tunç Çă̆ı'nın karakteristik seramiği olan Karaz (Kura-Aras) tipi seramik örneklerinin de bulunmasına karşın, yerleşimde daha çok yerel üretim seramiklerin kullanıldığı anlaşılmış̧ır. Yerleşimin büyük bir yangınla son bulduğu ve höyüğün MÖ 2200 yılında terk edildiği tespit edilmiştir. Erken Tunç Çağı kültür tabakasına ait tüm bilgiler mimari, seramik ve küçük buluntular ile de desteklenmiş ve radyokarbon tarihlemesi ile kanıtlanmıştır.

\section{Hayvan Figürinleri}

Anadolu'daki hayvan betimlemelerinin en erken örnekleri, Antalya'daki Epi-Paleolitik Dönem'e (Otte ve diğerleri, 1995), Kars ile Van-Hakkari Dağllk Bölgesi'ndekiler ise Neolitik Dönem'e tarihlenen mağara resimlerinde karşımıza çıkmaktadır (Sagona ve Zimansky, 2015: 26,30; Tümer, 2017: 174, Tab. 15-16). Daha sonra Göbeklitepe Çanak Çömleksiz Neolitik Dönem'e tarihlendirilen T şekilli taşlar üzerindeki hayvan tasvirleri (Schmidt, 2007: 114-162,259-265), Körtik Tepe'de aynı döneme tarihlendirilen taş kapları üzerindeki kazımalarda (Özkaya ve diğerleri, 2013: 15-17) görülen erken örnekler arasında sayılabilir. Çatalhöyük, Nevali Çori ve Çayönü gibi yerleşimlerde iyi bilinen tasvirler arasında sığır, koyun ve keçi çoğunluğu oluşturmaktadır. Bunların yanı sıra ayı, geyik, köpek gibi hayvanlar da görülmektedir (Morales, 1990: 58-60). Anadolu'da kilden yapılmış en erken hayvan figürinleri Nevali Çori (Hauptmann, 2007: 147-148) ve Çayönü (Çambel ve 


\section{F.Ü. Sosyal Bilimler Dergisi 2021-31/2}

Braidwood, 1980: 47; Özdoğan, 2007: 88) yerleşimlerinin Çanak Çömleksiz Neolitik Dönem tabakalarında bulunmuştur. Erken Neolitik Dönem'den itibaren ise hayvan figürini üretimi için kil daha çok tercih edilmeye başlanmıştır. Hayvanların kutsallığ Neolitik Dönem ve sonraki dönemlerde aynı şekilde devam etmiştir. Bu düşünce hayvanların krallar ve tanrılarla birlikte betimlenmesi ile de desteklenmektedir (Yücel, 2017: 151).

Hayvan betimlemelerinin ortaya çıkışı hakkında birçok farklı görüş bulunmaktadır. Bu görüşler arasında büyü ve doğanın kontrolü gibi sembolik düşünceler de bulunmaktadır. Bunlardan başka bir görüşe göre sosyal işlevlere bağlı olarak insan ve hayvan arasında manevi bağlantıların olduğu düşünülmektedir (Lewis-Williams, 2014). Diğer bir ileri sürülen görüşe göre ise hayvan figürinlerinin dinsel inanıştan çok günlük amaca hizmet ettiği ve hayvan heykelciklerinin "oyuncak" olduğu öne sürülmektedir (Morsch, 2002). İnsanların doğayı taklidi sonucu hayvan figürinlerinin ortaya çıktığı da düşünülmektedir. Bu nedenle bu figürinler dönemin doğal yaşamı hakkında bilgi vermesi ve hayvanların çeşitliliğini göstermesi bakımından da önemlidir. Ayrıca hayvan figürinleri dönemin sanat ve estetik anlayışını göstermesi bakımından da önemini korumaktadır.

Erken Tunç Çăğ'na ait ele geçen boynuzlu hayvan ve boğa betimlemeli figürinler, boynuzun ve boğanın kutsal sayıldığı dinsel bir inanışa bağlanabilir. Libasyon kaplarında da boynuzlu hayvan başları yaygın olarak kullanılmıştır. Dönemin geç evrelerinde ise dekoratif amaçlı yapılmış hayvan başı şeklinde kulp ve akıtacaklar görülmektedir. Daha geç dönemlerde ise hayvan figürinlerinde çeşitli süsleme tekniklerinin kullanıldığı görülmektedir (Sözen, 1999: 31).

Hayvan figürinleri genel olarak ayakta tasvir edilmişlerdir. Ancak örneklerin büyük çoğunluğu kırık olarak ele geçtiği söylenebilinir. Belli düşünceler çerçevesinde dönem insanları tarafından bilinçli olarak kırıldıkları düşünülmektedir. Ancak figürinlerin kasıtlı olarak kırılıp kırılmadıklarını anlamak oldukça zordur (Hodder, 2006: 9). Bu kanı, bütün dönemler için geçerliliğini korumaktadır.

\section{Murat Höyük Pişmiş Toprak Hayvan Figürinleri}

Murat Höyük'te 2019 yılında yapılan kurtarma kazı çalışmaları sırasında ele geçen figürinler, antropomorfik figürinler ${ }^{3}$ ve hayvan (zoomorfik) figürinler olmak üzere 2 başlık altında incelenmektedir. Bu çalışmada höyükten ele geçen hayvan (zoomorfik) figürinleri tüm detaylarıyla ele alınarak incelenmesi amaçlanmaktadır. Murat Höyük'te toplam dokuz adet pişmiş toprak hayvan figürini ele geçmiştir. Bu figürinler birbirine yakın benzer özellikler gösterseler de hayvan türlerine ve yüzey işlemlerine göre bazı farklılıklar göstermektedir. Bunlardan yedi tanesinin anatomik yapılarından dolayı boğa tasviri olduğu, diğer ikisinin ise koç/koyun tasviri olduğu düşünülmektedir. Tamamı elde şekillendirilen pişmiş toprak figürinlerde kısmi kırıklar vardır. $\mathrm{Bu}$ kırıklar bilinçli mi/kasıtlı mı kırıldığını, yoksa yapım aşamasında $\mathrm{m} ı$ meydana geldiğini veya uzun süre toprağın altında kalmasından dolayı mı hasarlandığını anlamak zordur. Bazen kazı çalışmaları sırasında buluntu anında bile kırıldığı bilinmektedir. Murat Höyük figürinlerinin kırıkları incelendiğinde, figürinlerin en hassas ve ince kırılgan kısımları olan baş, boynuz ve ayak kısımlarından daha çok kırıldığı görülmektedir. 3 ve 4 no.'lu örnekler hariç, bunlar gövdeden kırılmıştır.

Tamamı el yapımı olan hayvan figürinleri kiremit, açık kahve, açık kırmızı renkte hamura sahiptir ve hamur renginde astarlıdır. Figürinler genel olarak iyi pişirilmiştir. Bu figürinlerin ortalama 800-950 derecede açık bir seramik firınında pişirilmiş olduğu düşünülmektedir. ${ }^{4}$ Örneklerin bazılarının yüzeyinde pişmeden dolayı siyah alacalanmalar görülmektedir. Ele geçen eserler $5,8 \mathrm{~cm}-2,3 \mathrm{~cm}$ arasında değişen yüksekliğe; $4,7 \mathrm{~cm}-2,3 \mathrm{~cm}$ arasında değişen uzunluğa sahiptir. Ortalama 2-3 cm arasında değişen kalınlıklara sahiptirler.

Hayvan figürinlerinde, gözler ve burun gibi yüz detayları verilmiștir. Genelde dört ayağı üzerinde, ayakta durur bir şekilde boynuzlu ve kuyruklu olarak tasvir edilmişlerdir. Genellikle ince ve hassas olan boynuzlardan ve bacaklardan kırıktır. Özellikle boynuz ve kuyruk tasvirlerinde az da olsa boynuz şekli, kuyruk duruşları gibi bazı farklılıklar görülmektedir. Örneğin bir çok örnekte baştan dikine çıkan boynuz tasvirleri görülürken sadece bir örnekte (8.no.'lu) tam hilal biçimli boynuz görülmesi dikkat çekicidir. Kuyruk tasvirlerinde sağlam olarak

\footnotetext{
${ }^{3}$ Antropomorfik figürinler hakkında detaylı bilgi için bkz. Özdemir-Mutlu, 2020: 95-112.

${ }^{4}$ Murat Höyük Erken Tunç Çağı Seramiklerinin Arkeometrik analizlerini yapan Arkeometrist Doç. Dr. Ali Akın AKYOL, seramiklerin pişirilme derecelerinden yola çıkarak seramikle aynı kilden elde şekillendirilen figürinlerin de bu sıcaklıkta pişirilmiş olduğunu ön görmektedir.
} 
ele geçen az sayıdaki kuyruklardan iki farklı kuyruk tasviri tercih edildiği görülmektedir. Figürinlerin boynuz ve kuyruk tasvirlerinden topluluğun belirli bir hayvan türünün tasvirini tercih ettiği ve daha çok boğa ile ilişkilendirildiği söylenebilir. Höyükteki kilden yapılmış bütün hayvan figürinlerinde cinsel özellikleri gösteren uzuvlar belirtilmemiş̧ir. Figürinlerle ilgili daha detaylı anlatım katalog kısmında verilmiştir.

Höyükte ele geçen ilk iki boğa figürinin en belirgin özelliği ön bacakların bitişik ve yassı olarak yapılmasıdır (Kat. No. 1, Şekil 3.1; 4.1; Kat. No. 2, Şekil 3.2; 4.2). Her iki figürinin de arka bacakları kısmen korunmuştur ve kuyruk yapıları bellidir. Anatomik yapıları olarak güçlü bir vücut yapısına sahiptir. Bu güçlü anatomik yapılarından dolayı boğa olarak tasvir edildikleri düşünülmektedir. Boğa figürinin benzerleri, Pulur (Koşay, 1976a: Lev. 70.389,393) kazısında ve Yeniköy (Koşay, 1976b: Lev. 115.Y.72-135) kazılarının Erken Tunç Çağı tabakalarında ele geçmiştir. Ayrıca Norşuntepe (Hauptmann, 1979: Lev. 33.5) yerleşimdeki kilden boğa heykelciğinin kuyruk tasviri ile 2 no.'lu eserin kuyruk tasviri benzeşmektedir.

Murat Höyük kazı çalışmalarında ele geçen diğer iki hayvan figürinin ise koç/koyun olduğu düşünülmektedir (Kat. No. 3, Şekil 3.3; 4.3; Kat. No. 4, Şekil 3.4; 4.4). Her ikisi de el yapımıdır. Ele geçen figürinler krem renktedir, hamurun renginde astarlıdır ve iyi pişirilmiştir. Baş kısımları korunan örneklerde yüz kısmı sıkıştırılmış üçgen şeklindedir ve burun çıkıntıları aşağı doğru eğimlidir. 3 no.'lu örnekte başın iki yanında kulak/boynuz bulunmaktadır. Bu örnekte ön bacaklar sağlam ve aşağı doğru dik inmektedir. 4 no.'lu örnekte ise bacakların çıkış noktaları belli olsa da bacaklar kırıktır. Bu iki örneğin boynuzlarının baştan çıkış noktaları şüpheli olduğu için, boğa tasvirinden daha çok koç/koyun türü bir hayvanın tasvir edildiği düşüncesi hakimdir. Murat Höyük koç/koyun figürinlerinin benzerleri Norşuntepe (Schmidt, 2002: Taf.82.1288,1290,1292) ve Pulur (Koşay, 1976a: Lev. 70.381) kazısında ETÇ tabalarında ele geçmiştir.

Ele geçen diğer bir örnekte anatomik yapısı itibariyle güçlü bir boyun, baş kısmı sırt ile aynı hizada sonlanan, boynuz çıkıntılarının belirgin ama kırık olan bir boğa betimlemesi olduğu görülmektedir (Kat. No. 5, Şekil 3.5; 4.5). Burnu belirgin yapılan boğanın ön sol bacak ve arka sol bacak sağlam, sağ ve sol bacak ise kırık olarak ele geçmiştir. Bu örneğin arka ayakları kısa olarak tasvir edilmiştir. Bu figürinin en yakın benzerine Han İbrahim Şah kazısındaki ETÇ I ve ETÇ II tabakalarında rastlanılmışıı (Ertem, 1982: Lev. 26.225-226; Lev. 28.264; Ertem, 1982: Lev. 32.356).

Anatomik yapısı itibariyle güçlü bir boyun yapısı ile boğa tasvirini andıran 6. No.'lu örneğin, ön ve arka ayakları kısa olarak tasvir edilmiş̧ir (Kat. No. 6, Şekil 3.6; 4.6). Baş kısmı korunan bu örneğin yüz kısımları sıkıştırılmış üçgen şeklinde belirtilmiştir. Boynuzları kırık, kuyruk çıkıntısı belli ancak kuyruğu kırıktır.

Güçlü bir boyun ve karnı dolgun olarak betimlen 7 no.'lu örneğin, anatomik yapısı itibariyle boğanın vücut yapısının en iyi verilmiş örneklerden biridir (Kat. No. 7, Şekil 3.7; 4.7). El yapımı olan bu örnekte vücut hatlarının en iyi şekilde betimlendiği görülmektedir. Baş kısmı boyundan kırık, bacaklar ve kuyruk gövde başlangıcından kırık olarak ele geçmiştir. 
F.Ü. Sosyal Bilimler Dergisi 2021-31/2
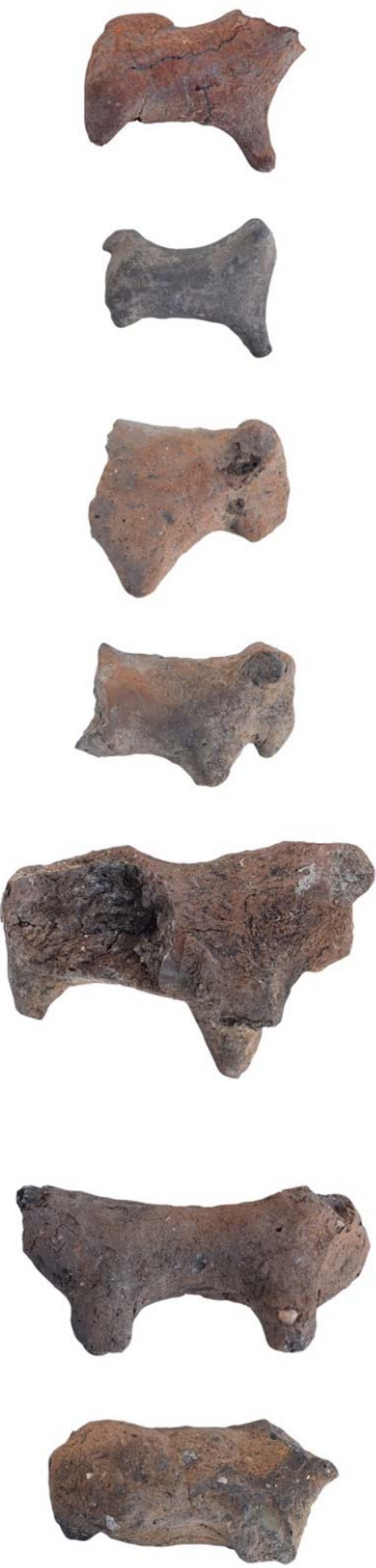
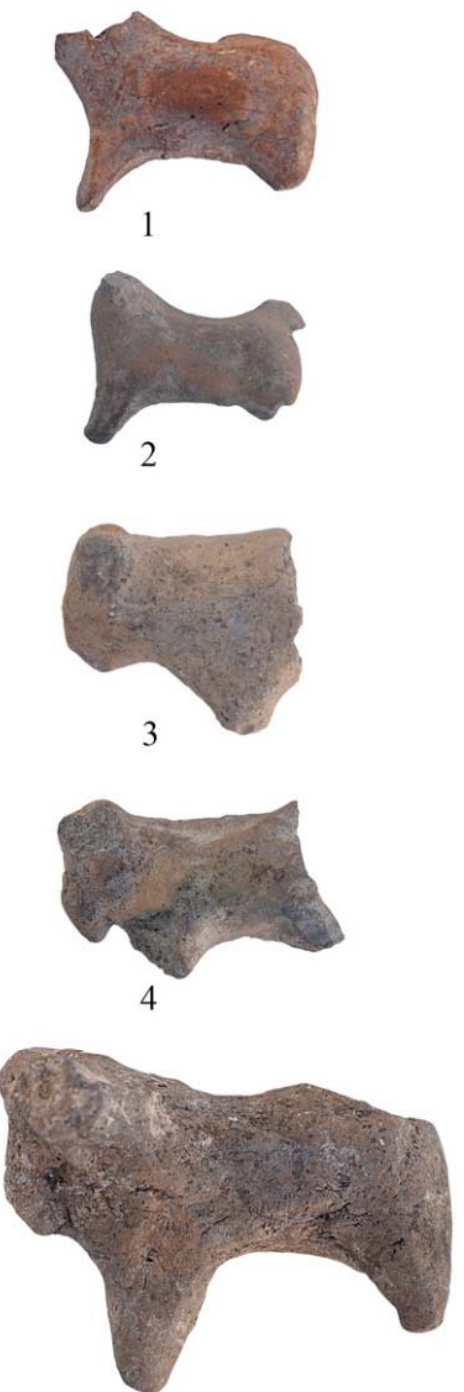

5

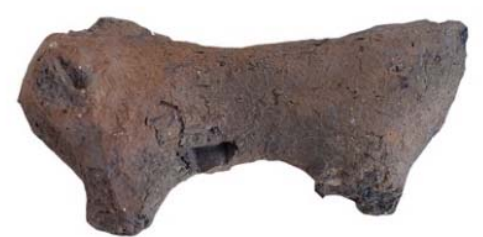

6

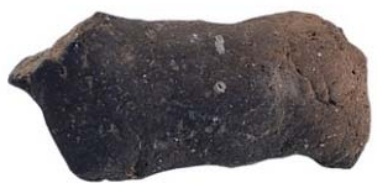

7

0

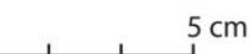

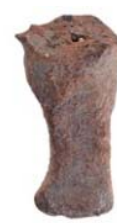
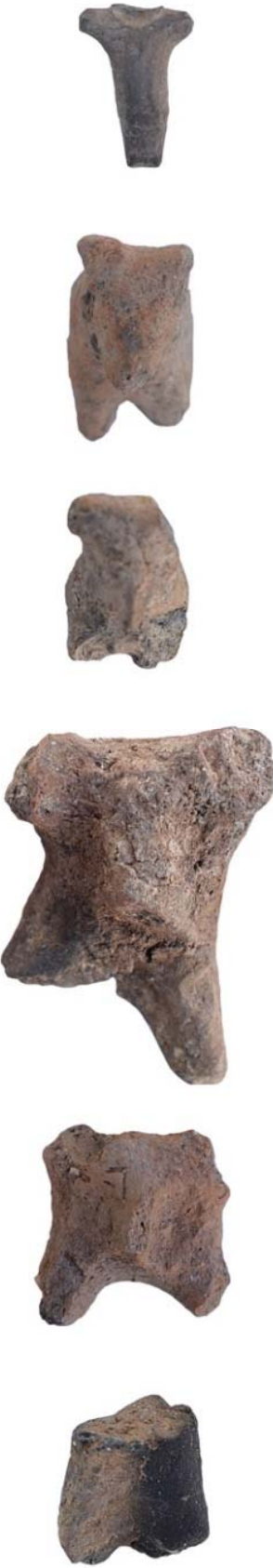

Şekil 3. Murat Höyük IV, 1-2, 5, 6 ve 7 No'lu Boğa Figürinleri, 3 ve 4 No'lu Koç/Koyun Figürinleri (Foto: Abdulkadir Özdemir). 

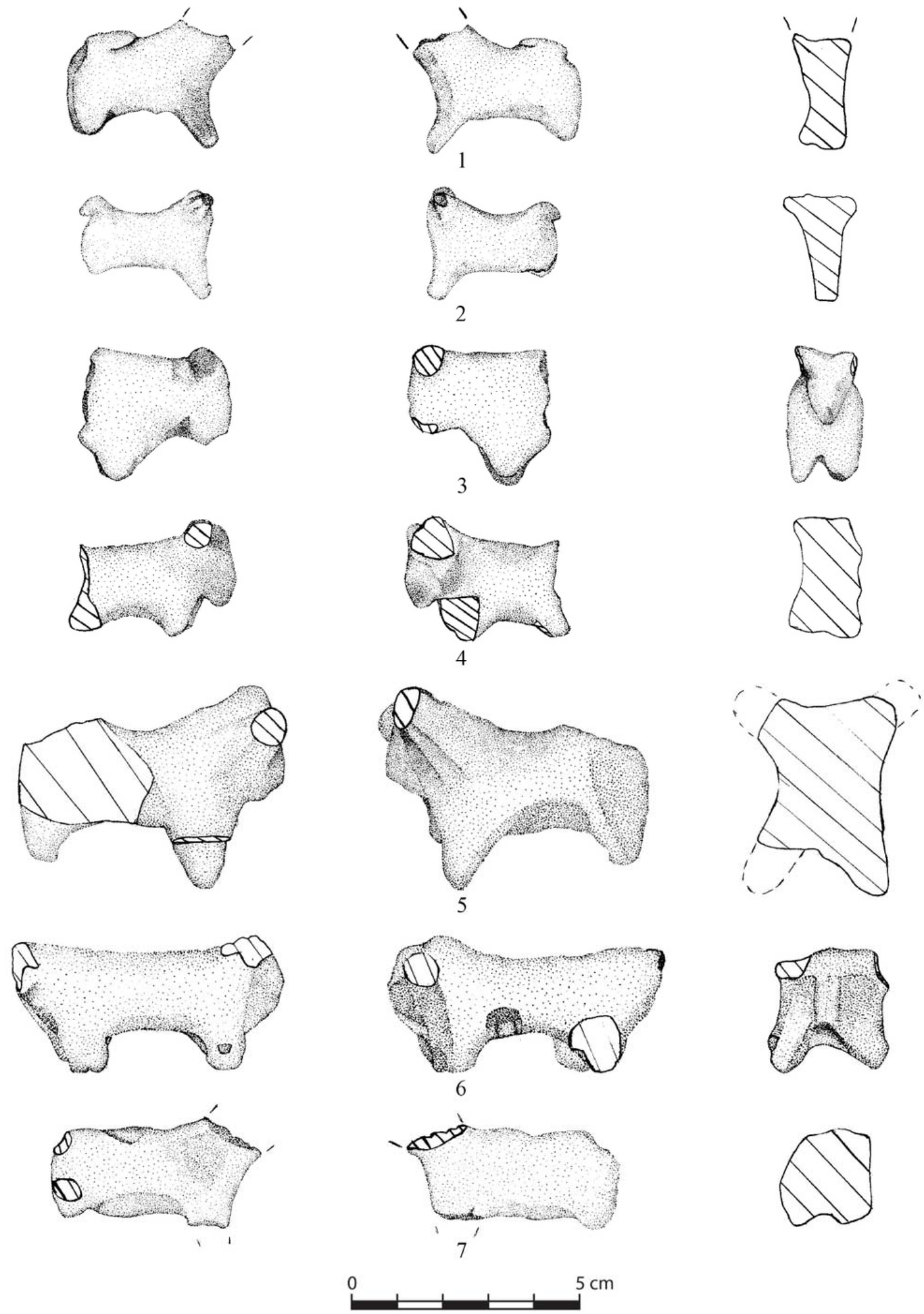

Şekil 4. Murat Höyük IV, 1-2, 5, 6 ve 7 No'lu Boğa Figürinlerin, 3 ve 4 No’lu Koç/Koyun Figürinlerin Çizimi (Çizim: Nurjiyan Özdemir). 


\section{F.Ü. Sosyal Bilimler Dergisi 2021-31/2}

1. Boğa Figürini (Şekil 3.1; 4.1): V-18 karelajı (Kazı Env. No: 209). El yapımı kil figürin, kiremit (10 R 6/6) hamurlu, hamurun renginde astarlı, orta kum-taşçık katkılı, iyi pişirilmiştir. El yapımı kil figürinin baş kısmı kırıktır. Ön bacaklar birleşik ve yassı, arka iki bacak ayrı şekilde yapılmıştır. Arka sağ bacak içten kırıktır. Kuyruk yukarıda, gövdeye doğru bitişik yapılmıştır. (Yük.: 2,7 cm, Uz.: 3,7 cm, Kal.: $2 \mathrm{~cm}$ ).

2. Boğa Figürini (Şekil 3.2; 4.2): V-18 karelajı (Kazı Env. No: 207). El yapımı kil figürin, açık kahve (10 YR 6/2) hamurlu, hamurun renginde astarlı, ince kum katkılı, pişme 1sısından dolayı yüzeyi siyah renktedir ve iyi pişirilmiştir. Figürinin yüz detayı belirtilmemiş, boynuzlar iki yanda yatay olarak verilmiş, iki boynuzun ortasında kırık bir alan bulunmaktadır. Ön bacaklar birleşik, tek bacak şeklinde ve yassıdır. Arka bacaklardan sol bacak kırıktır. Kuyruğu yassı formlu ve sağlamdır. (Yük.: 2,3 cm, Uz.: 2,9 cm, Kal.: 1,3 cm).

3. Koç / Koyun Figürini (Şekil 3.3; 4.3): U-18 karelajı (Kazı Env. No: 212). El yapımı kil figürin, krem (10 YR 7/2) hamurlu, hamurun renginde astarlı, ince kum-taşçık katkıl1, iyi pişirilmiştir. Figürinin baş kısmı ve gövdenin yarısı korunmuştur. Yüz sıkıştırılmış üçgen formludur ve sağ göz çukuru hafif belirtilmiştir. Kafanın iki yanında kulak ya da boynuz betimlenmiştir. Ön iki bacağı sağlamdır. (Yük.: 3,5 cm, Uz.: 2,9 cm, Kal.: 1,8 cm).

4. Koç / Koyun Figürini (Şekil 3.4; 4.4): U-19 karelajı (Kazı Env.No:208). El yapımı kil figürin, krem (7.5 YR 7/2) hamurlu, hamurun renginde astarlı, ince kum-taşçık katkılı, iyi pişirilmiştir. Figürinin baş kısmı sıkıştırılmış üçgen şeklinde ve burun çıkıntısı aşağıya doğru uzatılmıştır. Gözler belirtilmemiştir. Baş kısmının iki yanında boynuzlar yer almaktadır. Sağ boynuz belirgin, ucu kırık, sol boynuz kırıktır. Ön bacakların çıkış noktası belirgin ama kırıktır. Arka sol bacak çıkıntısı belirgin, sağ bacak ise gövdeden kırıktır. (Yük.: 2,5 cm, Uz.: 3,4 cm, Kal.: 1,8 cm).

5. Boğa Figürini (Şekil 3.5; 4.5): U-19 karelajı (Kazı Env. No: 211). El yapımı kil figürin, açık kahve (7.5 YR 6/4) hamurlu, hamurun renginde astarlı, ince kum-taşçık-az bitki katkılı, orta pişmiştir. Figürinin baş kısmı sıkıştırılmış üçgen şeklinde verilmiş, burun ve sol göz belirgin, boynuzlar kırıktır. Ön sol bacak sağlam, sağ bacak ise kırıktır. Arka sol bacak sağlam sol bacak kırıktır. Gövdenin sağ arka kısmı ve kuyruk kırıktır. (Yük.: 4,4 cm, Uz.: 5,8 cm, Kal.: 3 $\mathrm{cm})$.

6. Boğa Figürini (Şekil 3.6; 4.6): T-19 karelajı (Kazı Env. No: 210). El yapımı kil figürin, açık kırmızı (10 R 7/6) hamurlu, hamurun renginde astarlı, kaba kum, taşçık ve bitki katkılı, pişme nedeniyle yüzeyde renk değişimleri var, orta pişirilmiştir. Figürinin yüz kısmı sıkıştırılmış üçgen şeklinde belirtilmiştir. Boynuzları kırıktır. İnce, uzun bir gövdeye sahiptir. Arka ve ön bacaklar kırıktır. (Yük.: $3 \mathrm{~cm}$, Uz.: $6,1 \mathrm{~cm}$, Kal.: 2,5 cm).

7. Boğa Figürini (Şekil 3.7; 4.7): U-18 karelajı (Kazı Etüt No: 153). El yapımı kil figürin, açık kahve (10 YR 6/2) hamurlu, hamurun renginde astarlı, kaba kum, taşçık ve az bitki katkılı, pişme nedeniyle yüzeyinde siyah alanlar vardır, iyi pişirilmiştir. Figürinin baş kısmı kırıktır. Ön sağ bacak belirgin, sol bacak kırıktır. Sol arka ayak sağlam, sağ bacak ise kırıktır. Kuyruk kırıktır. Kalın ve kısa gövde yapısına sahiptir. Anatomik olarak güçlü boyun formu sırt ile aynı hizadadır. Dolgun bir karnı vardır. (Yük.: 2,4 cm, Uz.: 4,7 cm, Kal.: 1,9 cm).

Diğer bir örnekte yine anatomik yapısı itibariyle güçlü bir boyun sırt ile aynı hizada sonlanıyor, karnı dolgun, kuyruğu sağlam ve dikey yükselen hilal biçimli boynuz çıkıntısı görülmektedir (Kat No. 8, Şekil 5.8; 6.8). Bu figürinin sadece sol ön bacak sağlam diğer üç bacak kırık ve baş kısmı deforme olmuştur. Ele geçen diğer örneklerden farkı sağdaki boynuzunun dikey olarak yüksek, sağlam ve hilal biçimli olmasıdır. Kuyruk kısmı hafif aşağıya eğimli ve sağlamdır. 7 no.'lu örnekle birlikte boğanın vücut yapısı en iyi verilmiş örneklerden biridir. Bu örneğin boynuz tasviri bakımından Norşuntepe (Hauptmann, 1979: Lev. 33.5) kazılarında ele geçen kilden boğa heykelciğinin boynuz tasvirine benzemektedir.

Murat Höyük'te ele geçmiş olan son örnekte anatomik yapısı itibariyle güçlü bir boyun, ve baş sırt ile aynı hizada sonlandığı boğa betimlemesidir (Kat. No 9, Şekil 5.9; 6.9). Baştan dikey yükselen boynuzlar kırıktır, kuyruk bellidir. 6 no.'lu örnek gibi ön ve arka ayaklar kısa olarak tasvir edilmiş̧ir. 

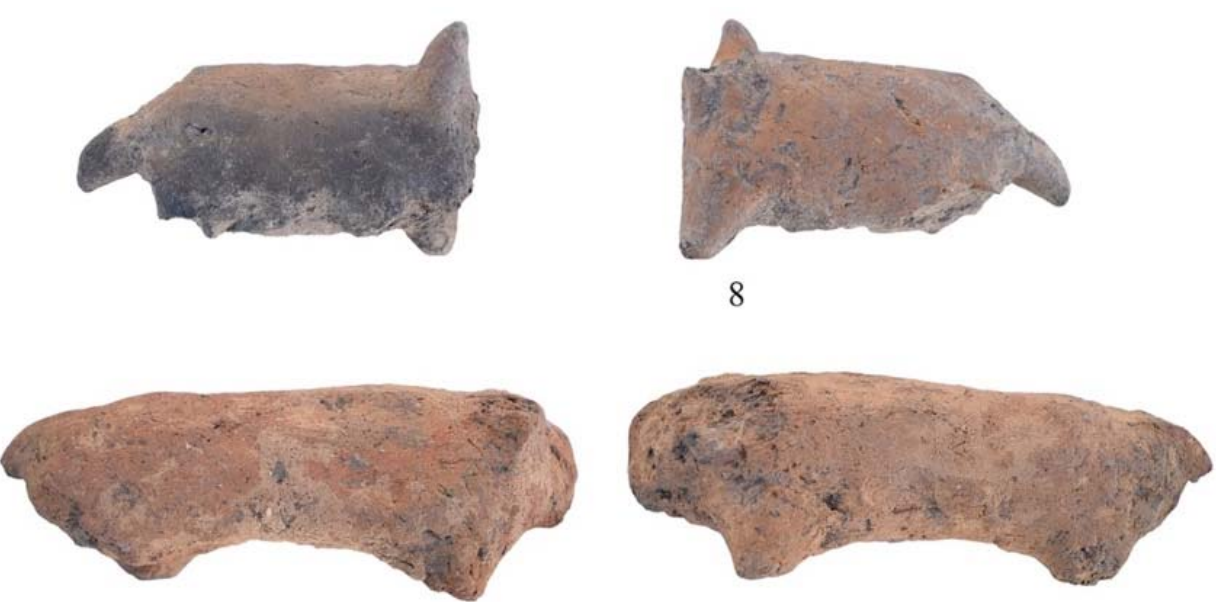

9

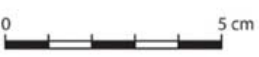

8
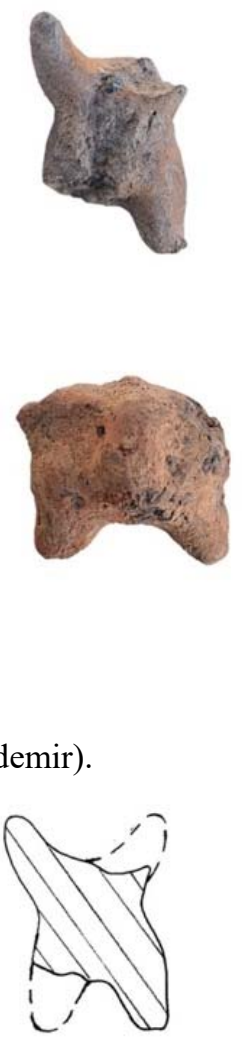

8
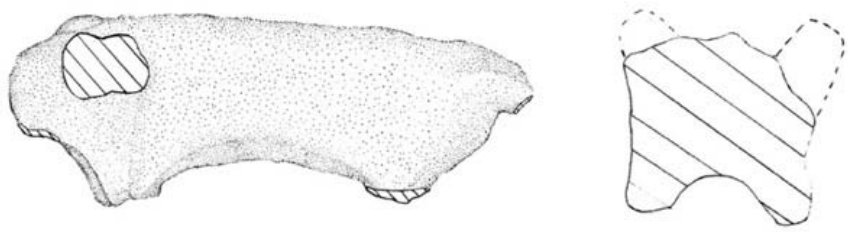

9

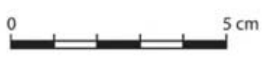

Şekil 6. Murat Höyük IV, 8 ve 9 No’lu Boğa Figürinlerin Çizimi (Çizim: Nurjiyan Özdemir).

8. Boğa Figürini (Şekil 5.8; 6.8) : T-20 karelajı (Kazı Env. No: 214). El yapımı kil figürin, açık kahve (2.5 YR 7/3) hamurlu, hamurun renginde astarlı, pişme nedeniyle yüzeyde alacalanmalar vardır. Orta kum-taşçı-bitki katkılı, iyi pişirilmiştir. Figürinin baş kısmı deforme olmuş, sağda dikey yükselen boynuz çıkıntısı sağlamdır. Sol boynuz kırıktır. Sol ön bacak sağlam diğer bacaklar ise kırıktır. Kuyruk sağlam ve hafif eğimle aşağı doğru belirtilmiştir. (Yük.: 5,8 cm Uz.: $8,8 \mathrm{~cm}$, Kal.: 2,8 cm).

9. Boğa Figürini (Şekil 5.9; 6.9): T-19 karelajı (Kazı Env. No: 215). El yapımı kil figürin, pembe (2.5 YR 7/6) hamurlu, hamurun renginde astarlı, kaba kum-taşçık-bitki katkılı, orta pişirilmiştir. Figürinin baş kısmı sıkıştırılmış üçgen şeklinde ve burun belirtilmiştir. Sağ ve sol boynuz belirtilmiş ancak kırıktır. Kısa ön bacaklar sağlamdır. Arka bacaklar kırıktır. Kuyruk çıkıntısı belli ancak kırıktır. (Yük.: 4 cm, Uz.: 12,2 cm, Kal.: 4 cm).

Bingöl, Murat Höyük çevresinde geçmiş yıllarda yapılan arkeolojik kazı ve sondajlarda benzer hayvan figürinleri ele geçmiştir. Özellikle Keban Baraj Projesi kapsamında kurtarma kazıları yürütülmüş olan ElazığMalatya bölgesindeki yerleşimlerin Erken Tunç Çağı tabakalarında benzer hayvan figürinleri bulunmuştur. Bunlardan; Han İbrahim Şah kazısında dört adet boğa heykelciği ele geçmiştir. Bunlar höyüğün ETÇ I ve ETÇ II tabakalarında tespit edilmiştir (Ertem, 1982: Lev. 26.225-226; Lev. 28.264; Ertem, 1982: Lev. 32.356). Pulur 


\section{F.Ü. Sosyal Bilimler Dergisi 2021-31/2}

kazısında yapılan çalışmalarda, Erken Tunç Çağı'na ait yirmi beş adet hayvan figürini bulunmuştur (Koşay, 1976a: Lev. 70.1 res.no.381; Lev. 70.18 res.no.405.). Yeniköy kazılarında Erken Tunç Çağı'na ait üç adet hayvan figürini ortaya çıkarılmıştır (Koşay, 1976b: Lev.115.Y.72-135; Lev.115.Y.72-32; Lev.115.Y.72-21). Norşuntepe (Hauptmann, 1979: Lev. 33.5.; Schmidt, 2002: Taf.XI.1298, Taf.XII.1261.25, 1251.56.57) kazılarında ise çok sayıda hayvan figürini ele geçmiştir. Ayrıca Tepecik Kazıları ETÇ I evresinde (Esin, 1982: Lev. 65.5,78.2), Değirmentepe (Duru, 1979: Lev. 6.3) yerleşimlerinde ve Kurban Höyük’te (Yücel, 2017: no. 2) birer adet Erken Tunç Çağı'na ait hayvan figürini ele geçmiştir. Erzurum Ovası'ndaki Alaybeyi Höyüğü kurtarma kazılarında Erken Tunç Çağı'na tarihlenen bir adet pişmiş topraktan hayvan figürini tespit edilmiştir (Iş̧klı, 2019: 158,160, Lev. 10a, Fot. 15).

Anadolu genelinde ise Erken Tunç Çağı'na ait hayvan figürinleri birçok yerleşimde karşımıza çıkmaktadır. Troia (Schliemann, 1976: 560), Kanlıgeçit (Özdoğan ve Parzinger, 2012: 200), Küllüoba (Deniz ve Ay, 2006; Ayten, 2019: 51, Fig.39), Demircihöyük (Korfmann, 1979: 26), Koçumbeli (Tezcan, 1966: 7, Lev. XXI,XXXIII-XXXIV; Ayten, 2019: 27,Fig.20), Çiledir Höyük (Türktüzün ve diğerleri, 2014: Res.25-26), Elmal1-Karataş (Warner, 1994: 197), Beycesultan (Lloyd ve Mellart, 1962: 269), Karataş-Semayük (Mellink, 1970: 250), Alişar (Von der Osten, 1937: Fig.185), Ahlatlıbel (Koşay, 1934: 87), Karaoğlan Mevkii (Topbaş ve diğerleri, 1998), Alacahöyük (Arık, 1937: Lev. CCXXI,Al.803,Al.1037, Lev. CLXI,Al.929), Titriş Höyük, Lidar Höyük ve Mezra Höyük (Karul ve diğerleri, 2017: 283,284,290) bu yerleşimler arasında sayılabilir.

\section{Değerlendirme ve Sonuç}

Bingöl İli Solhan İlçesi'ne bağlı Murat Köyü'nde, adını aldığı Murat Nehri kenarında konumlanan höyük, Aşağı Kaleköy Barajı Projesi su tutma havzası içerisinde kaldığından 2019 yılında kurtarma kazı çalışmaları yapılmış ve aynı yıl içerisinde çalışmalar tamamlanmıştır. Höyük 2020 yılının başlarında havzanın su ile dolmasının ardından sular altında kalmıştır. Murat Höyük kazı çalışmaları sırasında Erken Tunç Çağı III'e tarihlenen IV. tabakadan ele geçen hayvan figürinlerinden yedisi boğa figürini, ikisi koç/koyun figürini olmak üzere toplam dokuz adet pişmiş toprak hayvan figürini bulunmuştur.

Anadolu'da kilden yapılmış en erken hayvan figürinleri Nevali Çori (Hauptmann, 2007: 147-148) ve Çayönü (Çambel ve Braidwood, 1980: 47: Özdoğan, 2007: 88) yerleşimlerinin Çanak Çömleksiz Neolitik Dönem tabakalarında bulunmuştur. Erken Tunç Çağı'na gelindiğinde kilden yapılmış hayvan figürinleri sayısal olarak diğer dönemlere oranla daha fazla ele geçtiği bilinmektedir. Hayvan figürinleri hem sanatsal hem de dinsel yönden büyük öneme sahiptir. Dini açıdan gücü temsil eden boğa inancı insanların düşüncelerinde farklı bir yere sahip olduğu ve boğa boynuzları ile Ön Asya tanrı ve hükümdarlarının başlıklarının da süslendiği bilinmektedir (Halilov, 2013: 4). Boynuzlu hayvanlardan özellikle de boğa betiminin sevilerek kullanılmış olduğu anlaşılmaktadır. Boğanın yanında; koyun, keçi, koç, köpek, domuz, geyik, kuş gibi hayvan betimlemeleri de bulunmaktadır.

Murat Höyük kazıları sonucunda Erken Tunç Çağı III'e tarihlenen IV. tabakadan ele geçen hayvan figürinlerinin büyük kısmını boğalar oluşturmaktadır. Anatomik olarak güçlü bir vücut yapısına sahip olan boğalar kısmen kırıktır. Genel olarak figürinlerin dinsel bir ritüel sırasında kırılmış olabileceği düşünülse de bu konuda kesin olarak kırılma nedeni açıklanamamaktadır. Kırılmanın bilinçli mi yoksa zaman içerisinde toprak altında mı olduğu konusunda kesin bir sonuca varmak oldukça zordur. Yerleşimden ele geçen figürinler, baş, boyun, vücut, kuyruk, bacak yapısı olarak gerçeğe oldukça yakındır. Ancak hayvanlarda çok fazla ayrıntı görülmemektedir. Yüz kısımları sıkışıırılmış üçgen şeklindedir ve göz ya da burun yapıları net olarak işlenmemiş̧tir. Tüm Erken Tunç Çağı figürinleri gibi Murat Höyük figürinleri de oldukça sade ve basit olarak yapılmışıtır.

Murat Höyük IV. kültür katında yedi adet pişmiş toprak tekerlek ele geçmiştir. ${ }^{5}$ Küçük buluntular içerisinde tekerlekler ile boğa figürinleri bir bütün oluşturmaktadır. Murat Höyük'te ele geçen tekerleklerin, sağlam benzer model araba örneklerinde olduğu gibi (Piggott, 1968: 89; Piggott, 1969: Pl. XX-XXIV; Littauer ve Crouwel, 1974: Fig.1-2,8; Pl. I-II; Littauer ve Crouwel, 1990: 161, Fig.4), boğa/öküzler tarafından çekilen

\footnotetext{
${ }^{5}$ Pişmiş toprak Tekerlekler hakkında detaylı bilgi için bkz. Özdemir ve Çınar, 2021.
} 
vagon şeklinde bir araba modeline ait olabileceği düşünülmektedir (Şekil 7). Bazı tekerleklerin ise benzer örneklerde olduğu gibi (Piggott, 1969: Fig. 9), ayrıca avluda hayvan figürinleriyle birlikte ele geçmesi, bunların boğa/öküzler tarafından çekilen kağnı türü bir model olabileceğini düşündürmektedir (Şekil 8). Özellikle avludaki yangın tabakasından hayvan figürinleriyle birlikte ele geçen 3 adet (1, 2 ve 3 no.lu) tekerleğin (Şekil 9), daha çok bir boğa tarafından çekilen kağnı türünde bir model olduğu düşüncesini güçlendirmektedir (Özdemir ve Çınar, 2021). Yerleşimcilerin, avlu gibi açık alanlarda günlük yaşam faaliyetlerini sürdürdüğü, besin hazırlama ve tüketme gibi işlemleri toplu olarak yaptıkları düşünülürse; bu tekerleklerin daha çok iki tekerlekli kağnı türü veya dört tekerlekli vagon şeklindeki oyuncak olarak kullanılan minyatür arabaların parçası olduğu şeklinde yorumlanabilir (Özdemir ve Çınar, 2021). Ortak hareket eden insanların olduğu bir topluluk göz önüne alındığında ve bulunduğu mekânın avlu olmasına dayanarak, tekerleklerin boğa figürinleriyle birlikte oyuncak arabanın parçası olması çok daha olasıdır.

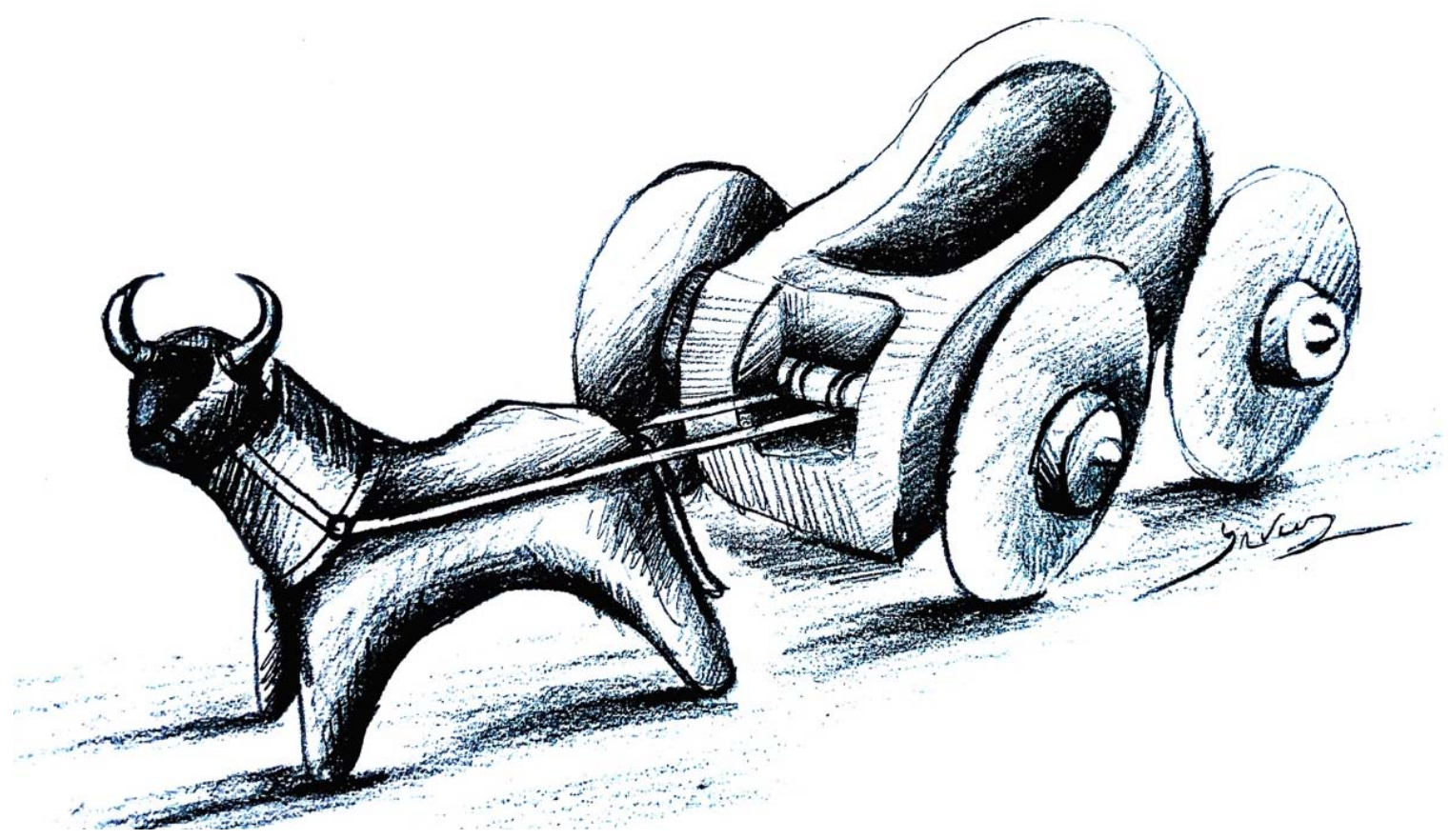

Şekil 7. Boğa Figürinin, dört tekerlekli vagon şeklindeki araba modeli ile işlevsel kullanımını gösteren Hipotetik Çizim (Çizim: Ressam Yavuz Deniz).

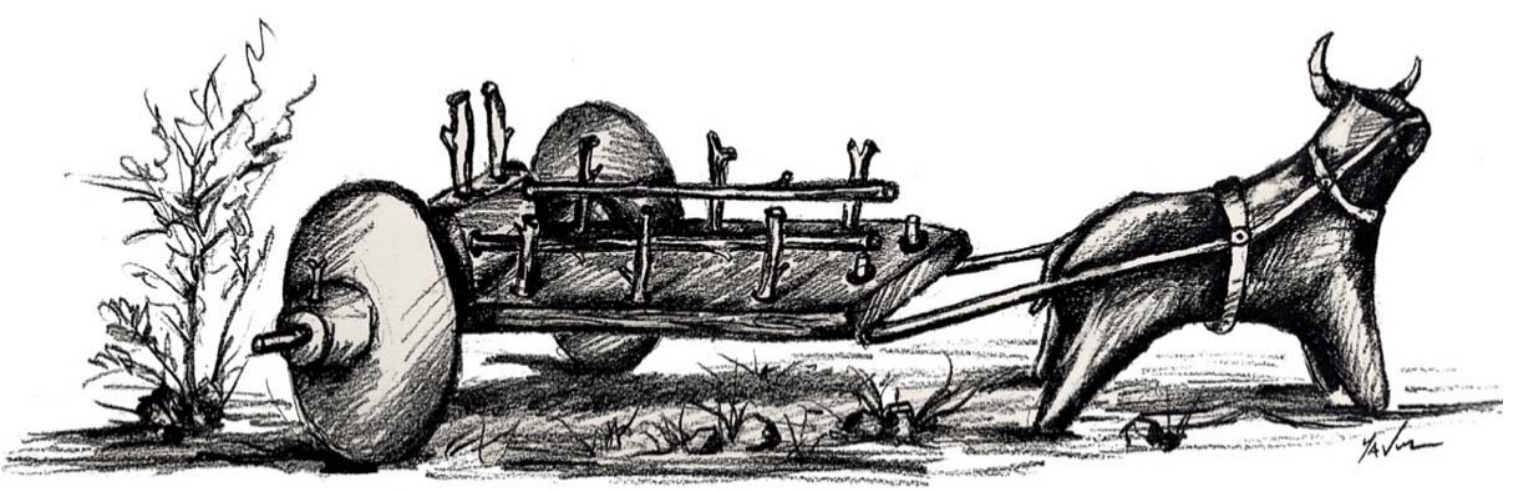

Şekil 8. Boğa Figürinin, iki tekerlekli kağnı türü bir araba modeli ile işlevsel kullanımını gösteren Hipotetik Çizim (Çizim: Ressam Yavuz Deniz). 

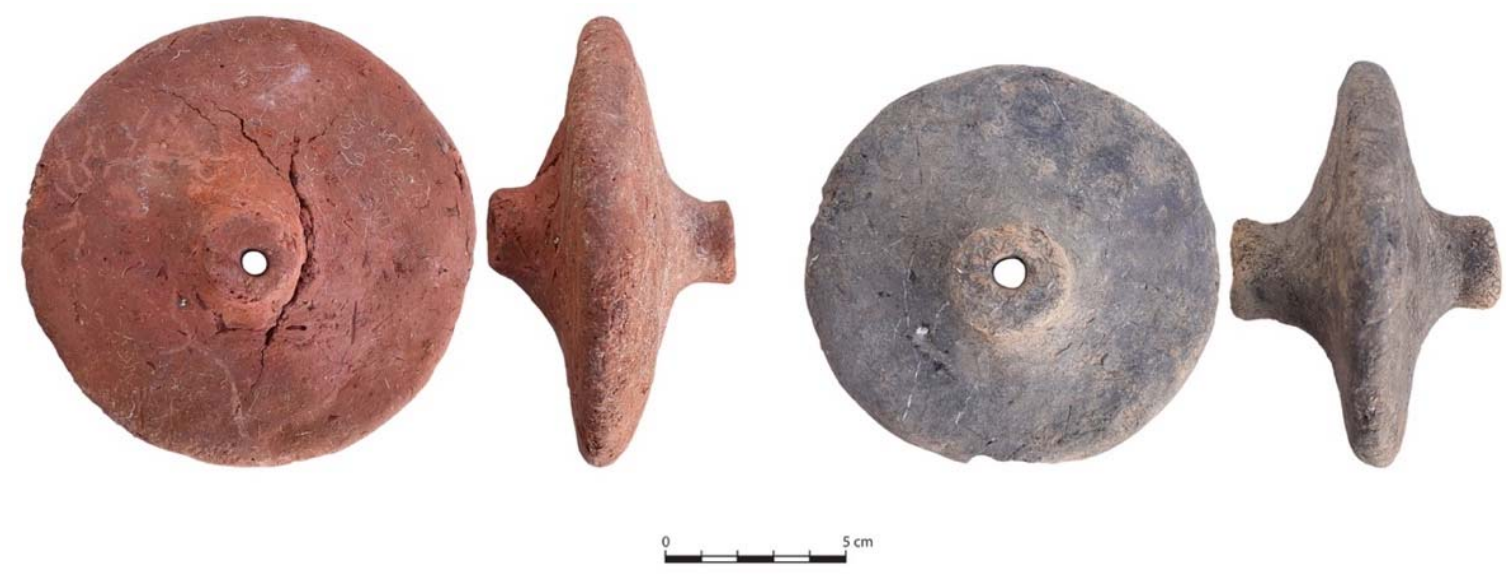

Şekil 9. Avlu'da hayvan figürinleriyle birlikte ele geçen 1 ve 2 No'lu Tekerlekler (Foto: A. Özdemir).

IV. kültür katında, tahılların depolandığı Mekân 4 içerisinde in situ olarak çeç damga mühür ve bir çömlek içinde karbonize olmuş çok sayıda tohum taneleri ele geçmiştir (Özdemir ve Özdemir, 2020: 134-135). Erken Tunç Çağı III'e ait olan Mekân 4 'te ki çömlek içindeki karbonize tahıl tanelerinin, arpa (Hordeum vulgare) ile ekmeklik/durum buğdayına (Triticum aestivum/durum) ait olduğu belirlenmiştir (Oybak Dönmez, 2021). Çeç mühürlerin sadece tarımsal faaliyetlerde kullanıldığı da bilinmektedir (Tekin, 2017: 233). Murat Höyük’te hem çeç damga mührün ele geçmesi hem de çok sayıda karbonize olmuş arpa ve ekmeklik/durum buğdayı ele geçmesi, yerleşimdeki tarımsal faaliyetlerin en önemli arkeolojik kanıtıdır. Ayrıca boğa, öküz, inek gibi büyük baş hayvanlara ait çok sayıda kemiklerin yerleşimde ele geçmesi, bu tür hayvanların topluluğun diyet listesinde olduğuna işaret etmektedir. Bu bağlamda hem tekerleklerin hem de hayvan figürinlerin ele geçmesi, tarım toplumlarında çok sık kullanılan boğa/öküzler tarafından çekilen kağnı türü iki tekerlekli bir modelin topluluk tarafından kullanılmış olduğu ileri sürülebilir.

Ege'de ve Anadolu'da Erken Tunç Çağı her alanda çok önemli değişimlerin öncüsü olmuştur. Özellikle Ege dünyasında ileri sürülen şeflik sistemi en köklü değişimler arasındadır (Renfrew, 1972). Ege'de tarım ekonomisindeki değiş̧iklikler, artan ürün çeşitliliği, öküz ve sabanın tarımsal teknolojisinde yoğun kullanılmaya başlandığını göstermektedir (Pullen, 1992). Ayrıca Ege'de tarımda öküz ve sabanın kullanıldığına dair arkeolojik örneklerde ele geçmiştir (Pullen, 1992: 49-54). Anadolu'da Erken Tunç Çağı, özellikle sosyo-politik bir otoritenin ortaya çıtı̆̆ı̆, yoğun bir şekilde iskan faaliyetlerinin arttığı ve daha çok tarımın yapıldığı bir dönemdir (Çevik, 2007: 131-138). Erken Tunç Çağı'nda bu tür önemli gelişmelerin bir sonucu olarak, tarımda boğa/öküz, saban ve kağnı türü araçların kullanıldığı ileri sürülebilir. Bu bağlamda; Murat Höyük'te Mekân 4 içerisinde ele geçen tohumlar, büyük baş hayvan kemikleri, boğa figürinleri ve tekerlekler bir bütün olarak düşünüldüğünde, Murat Höyük’te tarımsal teknolojinin bir yansıması olarak pişmiş toprak minyatür araç modellerinin ele geçtiği düşünülmektedir.

Murat Höyük boğa betimli figürinlerin gücü temsil etmesi yanı sıra, dinsel bir anlamı veya ritüel bir obje olarak kullanıldıkları bağlamında da düşünülebilir. Topluluğun, değer verdikleri nesneleri mekân içlerinde sakladıkları düşünülürse, kazı çalışmaları sırasında mekân içinde ele geçen örneklerden yola çıkılarak, boğa betimli figürinleri dinsel veya ritüel bir obje olarak kullanıldıkları da ileri sürülebilir.

Anadolu Erken Tunç Çağı'nda basit ve sade olarak pişmiş topraktan elde üretilen hayvan figürinlerinin birbirleriyle form açısından benzer özellikler göstermesi, ne amaçla üretildikleri konusunda bilim adamları tarafından 'dini ritüel amaçlı, adak, oyuncak, araba, bereket simgesi ve güç göstergesi' gibi farklı yorumlamalara sebep olmuştur. Murat Höyük'te ele geçen hayvan figürinlerinin işlevsel olarak da ne amaçla kullanıldıkları kesin olarak bilinmemekle birlikte, ele geçtĭgi tabakanın radyokarbon yöntemiyle tarihlendirilmesi, bu figürinlerin diğer Erken Tunç Çağı yerleşimlerinde ele geçen hayvan figürinleriyle form vb. karşılaştırma olanağı vermesi açısından Erken Tunç Çağı hayvan figürinleri repertuvarına katkı sağlayacağ düşünülmektedir. 


\section{Teșekkür}

Murat Höyük eserlerini çalışmama ve yayımlamama izin veren Murat Höyük Kazı Başkanı ve Elazığ Müze Müdürü Sayın Ziya KILINÇ’a içtenlikle teşekkür ederim. Kazının Bilimsel Danışmanlığı bu makalenin yazarı tarafından yapılmıştır. Murat Höyük kurtarma kazılarına gerekli izinleri verdiklerinden ötürü T.C. Kültür ve Turizm Bakanlığı Kültür Varlıkları ve Müzeler Genel Müdürlüğü’ne ve Elazığ Müzesi Müdürlüğü’ne teşekkür ederim. Kazı sezonu boyunca Bakanlık Temsilcisi olarak görev yapan Elazı̆̆ Arkeoloji Müzesi uzmanlarımızdan Ergün DEMIR'e teşekkürü bir borç bilirim. Ayrıca kurtarma kazısının finansörlüğünü yapan Kalehan Genç Enerji Üretim A.Ş. 'ye maddi ve manevi yardımlarından dolayı teşekkür ederim. Bu makaleye eleştirileri ve önerileri ile katkı yapan, eksiklerimin giderilmesinde yol gösteren Anonim hakemlere teşekkürü bir borç bilirim.

\section{Kaynaklar}

Arık, R. O. (1937). Les Fouilles D'Alaca Höyük: Entreprises par la Societe D'Histoire Turque, Rapport Preliminaire sur les Travaux en 1935. Publications de la Societe D'historie Turque V.Serie-No 1, Ankara. Aydıngün, Ş. G. (2006). Tunç Çă̆ı'nın Gizemli Kadınları. İstanbul: Yapı Kredi Yayınları.

Ayten, E. G. (2019). Animal Figurines During the Early Bronza Age of Anatolia: the case of Koçumbeli. (Yayınlanmamış yüksek lisans tezi). Orta Doğu Teknik Üniversitesi, Ankara.

Bilge, E. (2009). Diyarbakır Arkeoloji Müzesi'nde Bulunan Tunç Çă̆ı'na ait Figürinler. (Yayınlanmamış yüksek lisans tezi). Selçuk Üniversitesi, Konya.

Çambel, H. ve Braidwood, R. (1980). Güneydoğu Anadolu Tarih Öncesi Araştırmaları I. İstanbul: İstanbul Üniversitesi Edebiyat Fakültesi Yayınları.

Çevik, Ö. (2007). The Emergence of Different Social Systems in Early Bronze Age Anatolia: Urbanisation Versus Centralisation. Anatolian Studies, 57, 131-140.

Deniz, Ş. M. ve Ay, E. (2006). Küllüoba'da Bulunmuş Olan Pişmiş Toprak Figürinlerinden Birkaç Örnek. E. Özgen ve diğerleri (Ed.), Hayat Erkanal'a Armağan: Kültürlerin Yansıması içinde (90-94. ss.). İstanbul.

Duru, R. (1979). Değirmentepe Höyüğü Kazısı, 1973. Keban Projesi 1973 Çalışmaları içinde (Metin: 13-24. ss. Levha: 1-6). ODTÜ Keban Projesi Yayınları, Seri I, No:6, Ankara: Türk Tarih Kurumu.

Ertem, H. (1982). Keban Projesi Han İbrahim Şah Kazısı 1970-1971. ODTÜ Keban Projesi Yayınları Seri III, No:3, Ankara: Türk Tarih Kurumu.

Esin, U. (1982). Tepecik Kazıs1, 1974. Keban Projesi 1974-1975 Çalışmaları içinde (Metin: 71-118. ss. Levha: 53-78). ODTÜ Keban Projesi Yayınları, Seri I, No:7, Ankara: Türk Tarih Kurumu.

Halilov, T. (2013). Nahçivan'daki Erken Tunç Çă̆ı Yerleşimlerde Bulunmuş Kil Hayvan Figürinleri. Avrasya Uluslararası Araştırmalar Dergisi, Cilt:2, Sayı:3, 1-10.

Hauptmann, H. (1979). Norşuntepe Kazıları, 1973. Keban Projesi 1973 Çalı̧̧maları içinde (Metin: 43-78. ss. Levha: 16-45). ODTÜ Keban Projesi Yayınları, Seri I, No:6, Ankara: Türk Tarih Kurumu.

Hauptmann, H. (2007). Nevali Çori ve Urfa Bölgesinde Neolitik Dönem. M. Özdoğan ve N. Başgelen, (Ed.), Anadolu'da Uygarlığın Doğuşu ve Avrupa'ya Yayılımı Türkiye'de Neolitik Dönem: Yeni Kazılar, Yeni Bulgular içinde (131-164. ss.). İstanbul: Arkeoloji ve Sanat Yayınları.

Hodder, I. (2006). Figürinler Hakkında Düşünmek. Tunç Çă̆ı’nın Gizemli Kadınları içinde (7-10. ss.). İstanbul: Yapı Kredi Yayınları.

Işıkl1, M. (2019). Erzurum Ovası Alaybeyi Höyüğü Kalkolitik ve Erken Tunç Çağ Tabakaları. G. Altunkaynak (Ed.), Karaz'dan Büyük İskender'e Erzurum Ovası'nda Yeni Bir Keşif Alaybeyi Höyük içinde (139-182. ss.). Ankara: Bilgin Kültür Yayınları.

Karul, N., Kozbe, G. ve Yavuzkır, A. (2017). Şanlıurfa Müzesi Arkeolojik Eser Kataloğu. Kültür ve Turizm Bakanlığı Kültür Varlıkları ve Müzeler Genel Müdürlüğü Yayınları, Şanlıurfa Müzesi, Şanlıurfa.

Korfmann, M. (1979). Demircihöyük. Ist. Mitt. 29, 9-47.

Koşay, H. Z. (1934). Ahlatlıbel Hafriyatı. Türk Tarih, Arkeoloji ve Etnografya Dergisi, II: 3-100.

Koşay, H. Z. (1976a). Keban Projesi Pulur Kazısı 1968-1970. ODTÜ Keban Projesi Yayınları Seri III, No: I, Ankara.

Koşay, H.Z. (1976b). Yeniköy Höyüğü Kazısı, 1972. Keban Projesi 1972 Çalışmaları içinde (Metin: 175192. ss. Levha: 100-119). ODTÜ, Keban Projesi Yayınları, Seri I, No:5, Ankara: Türk Tarih Kurumu.

Lewis-Williams, J. D. (2014). The Mind in the Cave: Consciousness and the Origins of Art. NY: Thames \& Hudson.

Littauer, M. A. ve Crouwel, J. H. (1974). Terracotta Models as Evidence for vehicles with Tilts in the Ancient Near East. Proceedings of the Prehistoric Society, 40, 20-36. 
Littauer, M. A. ve Crouwel, J. H. (1990). A Terracott a Wagon Model from Syria in Oxford. Levant, 22(1), 160-162.

Lloyd, S. ve Mellart, J. (1962). Beycesultan I, The Chalcolithic and Early Bronze Age Levels. London.

Mellink, M. J. (1970). Excavations at Karataş-Semahöyük and Elmalı, Lycia, 1969. AJA 74, 245-253.

Morales, V. B. (1990). Figurines and Other Clay Objects from Sarab and Çayönü. Oriental Institute Communications 25: 57-88.

Morsch, M. G. F. (2002). Magic Figurines? Some Remarks about the Clay Objects of Nevalı Çori. H. G. K. Gebel, B. D. Hermansen ve J. C. Hoffmann (Ed.), Magic practices and ritual in the Near Eastern Neolithic içinde (145-162. ss.). Berlin.

Otte, M., Yalçınkaya, I., Leotard, J. M., Kartal, M., Bar-Yosef, O., Kozlowski, J. ve Marshack, A. (1995). The Epi-Palaeolithic of Öküzini cave (SW Anatolia) and its mobiliary art. Antiquity, 69(266), 931-944.

Oybak Dönmez, E. (2021). Murat Höyük Arkeobotanik Veriler-Tahıl Bereketi. A. Özdemir, Z. Kılınç, E. Demir (Ed.), Erken Tunç Çă̆ı'nda Murat Höyük içinde (Yayın Aşamasında).

Özdemir, A. ve Çınar, A. D. (2021). Early Bronze Age Terracotta Wheels from Murat Höyük. O. Dumankaya (Ed.), Arkeolojide Küçük Buluntular: Pişmiş, Toprak, Metal, Kemik, Cam ve Taş Eserler (Baskıda), Ankara.

Özdemir, A. (2020). Murat Höyük 2019 Excavation : A Preliminary Report. SDÜ Fen-Edebiyat Fakültesi Sosyal Bilimler Dergisi (51), 272-287.

Özdemir, [Ayşe]. ve Özdemir, A. (2020). Murat Höyük’ten Bir Çeç Damga Mühür. TÜBA-KED, 22, 131-139.

Özdemir, A. ve Mutlu, S. (2020). Murat Höyük Erken Tunç Çağı Antropomorfik Figürinleri. TÜBA-AR 27, 95-112.

Özdemir, A., Kılınç, Z. ve Ağtaş, Y. (2020). Aşağı Kaleköy Barajı Projesi/Murat Tepe 2018 Yılı Kurtarma Kazısı. Kazı Sonuçlan Toplantısı 41/1, 1-14.

Özdoğan, M. (2002a). İlk Adımlar Paleolitik Çağ. N. Karul, (Ed.). Arkeoatlas 1, 46-57.

Özdoğan, M. (2002b). Çanak Çömleksiz Neolitik Çă̆. N. Karul, (Ed.). Arkeoatlas 1, 66-83.

Özdoğan, M. (2007). Bazı Genellemeler-Öngörüler. M. Özdoğan ve N. Başgelen (Ed.), Anadolu'da Uygarlı̆̆ın Doğuşu ve Avrupa'ya Yayılımı Türkiye'de Neolitik Dönem: Yeni Kazılar, Yeni Bulgular içinde (441-458. ss.). İstanbul: Arkeoloji ve Sanat Yayınları.

Özdoğan, M. ve Parzinger, H. (2012). Die frühbronzezeitliche Siedlung von Kanlıgeçit bei Kırklareli: Ostthrakien während des 3. Jahrtausends v. Chr. im Spannungsfeld von anatolischer und balkanischer Kulturentwicklung. Studien im Thrakien-Marmara-Raum Band 3, Archäologie in Eurasien 27, Deutsches Archaäologisches Institut Eurasien-Abteilung, Verlag Philipp von Zabern, Darmstadt.

Özdoğan, A. (2007). Çayönü. M. Özdoğan ve N. Başgelen (Ed.), Anadolu'da Uygarlı̆̆ın Doğuşu ve Avrupa'ya Yayılımı Türkiye'de Neolitik Dönem: Yeni Kazılar, Yeni Bulgular içinde (57-97. ss.). İstanbul: Arkeoloji ve Sanat Yayınları.

Özgüç, T. ve Akok, M. (1958). Horoztepe, Eski Tunç Devri Mezarlı̆̆ı ve İskân Yeri. Horoztepe, an Early Bronze Age Settlement and Cemetery. Ankara.

Özkaya, V., Coşkun, A. ve Soyukaya, N. (2013). Körtik Tepe: Uygarlığın Diyarbakır'daki Illk Adımları. İstanbul: Arkeoloji ve Sanat Yayınları.

Piggott, S. (1968). The Beginnings of Wheeled Transport. Scientific American, 219, 82-93.

Piggott, S. (1969). The Earliest Wheeled Vehicles and the Caucasian Evidence. Proceedings of the Prehistoric Society, 34, 266-318.

Pullen, Daniel J. (1992). Ox and Plow in the Early Bronze Age Aegean. American Journal of Archaeology, Vol. 96, No: 1, 45-54.

Renfrew, C. (1972). The Emergence of Civilisation: The Cyclades and the Aegean in the Third Millennium B.C. London.

Sagona, A. ve Zimansky, P. (2015). Arkeolojik Veriler Işığııda Türkiye’nin En Eski Kültürleri MÖ 1.000.000550. İstanbul: Arkeoloji ve Sanat Yayınları.

Schliemann, H. (1976). Ilios the City and Country of the Trojans. USA.

Schmidt, K. (2007). Taş Çă̆ı Avcılarının Gizemli Kutsal Alanı Göbekli Tepe: En Eski Tapınă̆ı Yapanlar (R. Aslan Trans.). İstanbul.

Schmidt, K. (2002). Norşuntepe Klleinfunde II, Artefakte aus Felsgestein, Knochen und Geweih, Ton, Metall und Glas. Verlag Philip von Zabern, Mainz am Rhein.

Sözen, Ö. (1999). Batı Anadolu'nun MÖ III. ve II. Bin'e ait Pişmiş Toprak Figürinleri. (Yayınlanmamış yüksek lisans tezi). Ankara Üniversitesi, Ankara. 
Tekin, H. (2017). Hakemi Use'den Bir 'Pintadera'. S. Özkan, H. Hüry1lmaz ve A. Türker (Ed.), Samsat'tan Acemhöyük'e Eski Uygarlıkların İzinde Aliye Öztan'a Armă̆an içinde (231-238. ss). İzmir: Ege Üniversitesi Rektörlüğü Basımevi Müdürlüğü.

Tezcan, B. (1966). 1964 Koçumbeli Kazısı. Koçumbeli village excavation 1964. Ankara: Türk Tarih Kurumu Basımevi.

Topbaş, A., Efe, T. ve İlaslı, A. (1998). Salvage excavations of the Afyon archaeological museum, part 2: the settlement of Karaoğlan Mevkii and the Early Bronze Age cemetery of Kaklık Mevkii. Anatolia Antiqua, 6, 21-94.

Tümer, H. (2017). Van-Hakkari Dağlık Bölgesi Kaya Resimleri. (Yayınlanmamış yüksek lisans tezi). İstanbul Üniversitesi, İstanbul.

Türktüzün, M., Ünan, S. ve Ünal S. (2014). Çiledir Höyük Erken Tunç, Çağı II Bulguları. TÜBA-AR 17,49-72.

Von der Osten, H. H. (1937). Researches in Anatolia 7. The Alishar Hüyük Seasons of 1930-1932, Part 1. The University of Chicago Press.

Warner, J. L. (1994). Elmall-Karataş II: The Early Bronze Age Village of Karataş. Oxford.

Yücel, Ç. (2017). Şanlıurfa Müzesinden Bir Grup Hayvan Biçimli Pişmiş Toprak Figürin. Sosyal Bilimler Dergisi, 4(18), 149-171. 